\title{
DIGITAL HEALTH AND ILLNESS: BALANCING IT
}

\author{
António Bandeira ${ }^{1}$ and Henrique Martins ${ }^{2}$ \\ ${ }^{1}$ Faculdade de Medicina da Universidade do Porto, Portugal \\ ${ }^{2}$ ISCTE-IUL, Portugal
}

\begin{abstract}
Digital Illness can be conceptualized as a state of less health resulting from either "too much" or "too little" exposure to the Digital. In order to evaluate the state of health we suggest the use of the Health Index. It will allow us to measure the level of Health of each person in each moment. This Health Index is negatively affected by the under and overuse of the Digital. In order to best benefit from the Digital, we have to understand how much the right amount of Digital is, which maximizes the Health Index of the individual. To do this we have to understand the extremes of "too little" and "too much" Digital. In what concerns the use of "too much" Digital, we divide this topic in four areas, and we present evidence regarding the existence of each of those areas.
\end{abstract}

\section{KEYWORDS}

Digital Illness, Digital Obesity, Digital Sickness, Digital Addiction, Digital Overdose, Digital Accident

\section{INTRODUCTION}

There is no doubt that technology plays today an essential role in our daily lives. It is present in almost everyday strands of our daily lives. In order to collect the best from Digital, first we must understand that it is over, and underuse entail different but very important problems in what concerns our health. This understanding will help us to comprehend better where we can find the turning point from where more digital does not mean more health but, on the contrary, it starts to mean a reduction in our health.

In what concerns Digital Illness, it can be conceptualized as a state of less health resulting from either "too much" or "too little" expositor to digital means in today's reality. It may occur as people experience lack or excess of Digital. One could say that lack of digital leads certainly to Digital Segregation as is the case with over $21 \%$ of people in Portugal and higher percentage worldwide with no access to internet/digital means and with less access to health literacy and even digital health services such as tele-health. Excess of digital seems more evidently harbor more pathological potential as it can leads to various problems that should also receive our attention. In this paper we will reflect mainly about the problems entailed by the digital overuse. To do this we suggest the use of a new concept - the Health Index (HI).

\section{BODY OF PAPER}

In order to evaluate the impact of any agent that change our level of health, we must first be able to measure our level of health. In any day of a person's life is possible to be $100 \%$ healthy neither $100 \%$ sick. Accordingly, we must understand how much the percentage of our healthy and unhealthy self is in every day of our life, and how to manage that. To do this we suggest the use of the concept of HI. This variation of our HI happens not only along the day, but also along our lives, and even beyond! HI is a concept that may be applied since before birth until after death! When talking about before birth we should think about the fluctuations of our health that modifies our HI, even when we are still a fetus inside of a uterus. In what concerns the after death we may think about a possible organ donation, where "our" organs still face state variations that change HI. The "basal" health level is modified by HI, either increasing (when positive) or decreasing (when negative). It is also important to understand that $\mathrm{HI}$ is variable in time, changing its value each moment. Thus, HI can be a broadly applied concept. 
Assuming Health status is a moving constant, we can conceptualize it to range from "total health", to total Sickness (near death situation). As such a health index (HI) could be conceived to range between 100\%, meaning totally healthy, and $-100 \%$ meaning totally sick. The option of using $-100 \%$ is made on purpose as moving constant daily and even hourly can be assumed for "health" as a "measurable" entity. As we already stated, no one is either on the upper or lower end for, eventually, more than a few instants. In what concerns to the topic of this paper, we understand that not only the little exposition to Digital leads to a lower HI, but also too much exposition leads to an equally low HI (as an example, the over digital professional aspect of life can have a high impact). Taking this into account, it is important to understand each one of these extremes in order to accomplish the appropriate exposition to Digital that enhances our HI as close to 100\% as possible. Actually there are already studies suggesting the use of "personalized Family Media Use Plans" (Reid Chassiakos et al., 2016).

As already stated, we intend to reflect about the different areas that negatively impact our HI due to Digital Overuse. According with our research the Digital Illness due to excess of digital may be divided in four main areas. Digital Overweight/Obesity, Digital Sickness, Digital Addition/Overdose and Digital Accident/Death. In the next paragraphs we will sum up existing scattered evidence for each one of these areas. To facilitate the understanding, we organized this concepts on Figure 1. On Table 1 we share some evidence about each one of this area regarding Digital illness due to Digital Excess.

\subsubsection{Digital Obesity/Overweight}

In what concerns to the concept of Digital Overweight/Obesity there are complaints about almost all aspects of our lives. From physical symptoms, as vision and tendinitis, neurological symptoms, as irritation, mental symptoms, as information overload, to psychiatric symptoms as Burnout. A very current example of this Digital Obesity is the one that we are living with the Covid-19 pandemic. Every day we are bombed with so many information, either true or negative, that our anxiety levels rise due, not only to the disease, but also to the enormous amount of information. (Rathore and Farooq, 2020)

\subsubsection{Digital Sickness}

When there is discomfort and pathology, we start to refer it as Digital Sickness. In this area we have very aspects to consider.

The concept of Digital Anorexia / Role Play refers to those who "see" themselves in a different way when compared to who they really are. This happens due to an altered perception of who they really are.

Dependency Syndrome refers to those who need approval for their ideas on social media.

Also, there are some people that have Multiple Personalities or personality dysmorphia, that changes accordingly with the fact that they are in the "real world" or on the social media.

\subsubsection{Digital Addiction/Overdose}

A more understandable concept is the Digital Addition and Digital overdose. Now, more than ever, we pursue the digital to every place where we go, many times, over the social norms. For example, when we ask for the Wi-Fi password even before a nice compliment to the waitress or when we keep checking our phone when we are at the dinner table or in a bar with friends or family.

\subsubsection{Digital Accident/Death}

Last, but not the least, there is a growing number of accidents due to the digital. Not only traffic accidents, both from distracted pedestrians being hint by cars as they surf their smartphone to more abstract yet harmful social rupture, where people are physically alive but so disconnected that they do "not live" or "are dead" to those around them. Regarding this specific area, it is important to remember that wearables also represent a risk to our health, in what concerns traffic accidents (Sacks et al., 2018).

\subsection{Figures and Tables}
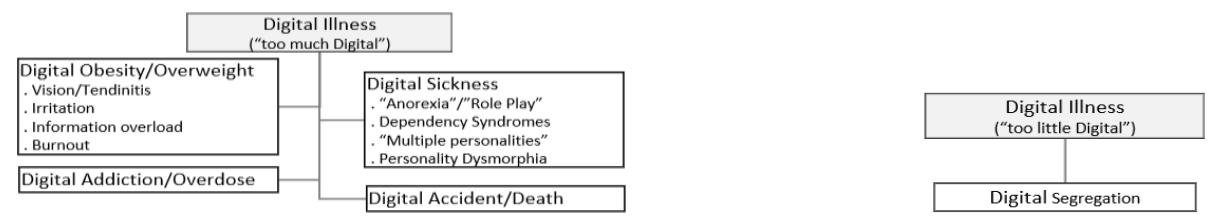

Figure 1. Digital Illness 
Table 1. Exemplar papers about the Different Areas of Digital Illness due to "too much Digital"

\begin{tabular}{|c|c|c|}
\hline Author & Main Messages & Topic \\
\hline $\begin{array}{l}\text { (Klerings et } \\
\text { al., 2015) }\end{array}$ & $\begin{array}{l}\text { "It results in a richer range of resources to support practice and learning, but also creates } \\
\text { conflicting evidence, insecurity about the knowledge and greater demands on the professional to } \\
\text { identify the appropriate knowledge for their problem in question.", } \\
\text { "Filtering the information overload for better decisions" }\end{array}$ & $\begin{array}{l}\text { Digital Obesity } \\
\text { / Overweight }\end{array}$ \\
\hline $\begin{array}{l}\text { (Byyny, } \\
\text { 2016) }\end{array}$ & $\begin{array}{l}\text { "average workers spend } 28 \% \text { of their time managing e-mail"; "we check our phones on average } \\
221 \text { times a day, or about every } 4.3 \text { minutes"; } \\
\text { "nearly one in eight Americans exhibit problematic Internet use" } \\
\text { "average young adult moves between media platforms } 27 \text { times per hour, which can lower IQ by } \\
\text { as much as } 15 \text { points" }\end{array}$ & $\begin{array}{l}\text { Digital Obesity } \\
\text { / Overweight }\end{array}$ \\
\hline $\begin{array}{l}\text { (Lee et al., } \\
\text { 2017) }\end{array}$ & $\begin{array}{l}\text { "we operationally define information overload as either a perceived or actual occurrence } \\
\text { whereby the volume or complexity of information accessed by an individual exceeds their } \\
\text { capacity to process the information within a given timeframe" }\end{array}$ & $\begin{array}{l}\text { Digital Obesity } \\
\text { / Overweight }\end{array}$ \\
\hline $\begin{array}{l}\text { (Milne, } \\
\text { 2019) }\end{array}$ & $\begin{array}{l}\text { Clinicians should not feel threatened or frustrated by informed patients; instead, we should see } \\
\text { this as an opportunity to challenge our own perceptions and address misinformation. } \\
\text { How do we use the information to best effect? How does health literacy of the public and co- } \\
\text { workers impact information giving and how do our beliefs and values influence the processing of } \\
\text { information? What is our sphere of influence? What do we need people to know to enable care? }\end{array}$ & $\begin{array}{l}\text { Digital Obesity } \\
\text { / Overweight }\end{array}$ \\
\hline $\begin{array}{l}\text { (Rathore } \\
\text { and Farooq, } \\
\text { 2020) }\end{array}$ & $\begin{array}{l}\text { COVID-19. "infodemic" in which false news, conspiracy theories, magical cures and racist news } \\
\text { are being shared at an alarming rate, with the potential to increase anxiety and stress and even } \\
\text { lead to loss of life. }\end{array}$ & $\begin{array}{l}\text { Digital Obesity } \\
\text { / Overweight } \\
\text { Digital } \\
\text { Accident/Death }\end{array}$ \\
\hline $\begin{array}{l}\text { (Steele et al., } \\
\text { 2020) }\end{array}$ & $\begin{array}{l}\text { "social media use specifcally can be associated with diminished psychological functioning in } \\
\text { adolescents and young adults" } \\
\text { Related with "digital stress: including availability stress, approval anxiety, fear of missing out, } \\
\text { and communication overload" }\end{array}$ & $\begin{array}{l}\text { Digital } \\
\text { Sickness }\end{array}$ \\
\hline $\begin{array}{l}\text { (Mihajlov } \\
\text { and } \\
\text { Vejmelka, } \\
\text { 2017) }\end{array}$ & $\begin{array}{l}\text { The difficulty in finding a precise definition of Internet Addiction makes it harder to classify, } \\
\text { measure, diagnose, treat and prevent this Addiction. } \\
\text { There are many different types of Internet Addictions that should be faced differently. } \\
\text { About Prevention: Universal Prevention, Selective Prevention, Indicated Prevention }\end{array}$ & $\begin{array}{l}\text { Digital } \\
\text { Addiction / } \\
\text { Overdose }\end{array}$ \\
\hline $\begin{array}{l}\text { (Eichenberg } \\
\text { et al., 2017) }\end{array}$ & $\begin{array}{l}\text { There is a positive relation between Insecure attachment style (Attachment Theory). } \\
\text { Users with Internet Addiction (report different motives for Internet use when compared with } \\
\text { users without Internet Addiction. }\end{array}$ & $\begin{array}{l}\text { Digital } \\
\text { Addiction / } \\
\text { Overdose }\end{array}$ \\
\hline $\begin{array}{l}\text { Kuss and } \\
\text { Griffiths, } \\
\text { 2017) }\end{array}$ & $\begin{array}{l}\text { "Social Networking Sites and Addiction: Ten Lessons Learned: (i) social networking and social } \\
\text { media use are not the same; (ii) social networking is eclectic; (iii) social networking is a way of } \\
\text { being; (iv) individuals can become addicted to using social networking sites; (v) Facebook } \\
\text { addiction is only one example of SNS addiction; (vi) fear of missing out (FOMO) may be part of } \\
\text { SNS addiction; (vii) smartphone addiction may be part of SNS addiction; (viii) nomophobia may } \\
\text { be part of SNS addiction; (ix) there are sociodemographic differences in SNS addiction; and (x) } \\
\text { there are methodological problems with research to date." }\end{array}$ & $\begin{array}{l}\text { Digital } \\
\text { Addiction / } \\
\text { Overdose }\end{array}$ \\
\hline $\begin{array}{l}\text { (Kircaburun } \\
\text { and } \\
\text { Griffiths, } \\
\text { 2018) }\end{array}$ & Relationship between personality and social networking site addiction (Instagram®) & $\begin{array}{l}\text { Digital } \\
\text { Addiction / } \\
\text { Overdose }\end{array}$ \\
\hline $\begin{array}{l}\text { (Atchley } \\
\text { and Strayer, } \\
\text { 2017) }\end{array}$ & $\begin{array}{l}\text { Using a cell phone while driving was one of the most common sources ( } 12 \%) \text { of distraction } \\
\text { recorded in the } 6 \text { seconds before the crash. } \\
\text { "The National Safety Council estimates that approximately one-quarter of the crashes in the } \\
\text { United States are because of small-screen distraction" } \\
\text { "In } 1 \text { survey, } 2 \text { nearly one-third ( } 31 \%) \text { of the respondents reported texting when they were } \\
\text { distressed (including being bored), one-quarter ( } 24 \%) \text { reported texting when it was socially } \\
\text { inappropriate, one-fifth ( } 20 \%) \text { reported texting when it was dangerous, and nearly one-fifth } \\
(17 \%) \text { reported feeling the need to increase how much they texted" }\end{array}$ & $\begin{array}{l}\text { Digital } \\
\text { Sickness - } \\
\text { Dependency } \\
\text { Syndromes }\end{array}$ \\
\hline $\begin{array}{l}\text { (Sacks et al., } \\
\text { 2018) }\end{array}$ & $\begin{array}{l}\text { "if drivers intuitively believe or are frequently told that Google Glass is less disruptive to driving } \\
\text { performance than smartphones, our current data showed that frequent use and quick access to } \\
\text { wearable devices (such as Google Glass) in actual daily driving may potentially put wearable } \\
\text { device users at higher risks than smartphone users." } \\
\text { "although wearable devices, voice recognition and head-mounted display, are designed in a hope } \\
\text { to reduce visual and manual distraction and these technologies do work to some extents, } \\
\text { however, these technologies are not distraction-free or risk-free. Drivers are discouraged to } \\
\text { engage in distraction tasks not just in a smartphone, but also Google Glass and smartwatch, as all } \\
\text { these devices impair driving performance" }\end{array}$ & $\begin{array}{l}\text { Digital } \\
\text { Accident / } \\
\text { Death }\end{array}$ \\
\hline
\end{tabular}




\begin{tabular}{|l|l|l|l|l} 
(Ortiz et al., & "texting WhatsApp messages while driving worsens driving performance for all age groups, & Digital \\
2018) & most notably among older participants." & Accident / \\
"negative effect of the use of the smartphone during driving was also reflected in the number of & Death \\
collisions, with a greater risk of accidents in all the groups of drivers (by $8.3 \%$ for young adults, & 25.0\% for adults, $80.5 \%$ for middle-aged adults, and $134.5 \%$ for older drivers)" \\
& "participants' subjective responses indicated that younger drivers (18-24 years) had a higher risk \\
of deliberately violating safe driving practices $(\mathrm{p}<0.05) . "$
\end{tabular}

\section{CONCLUSION}

We may define the Digital Illness as any negative impact of Digital on Health. The concept of a Health Index (HI) is presented and used to plot $\mathrm{HI}$ versus digital exposure, creating different clusters of problematic areas. This negative impact of digital in humans can happen either due to a lack or excess of Digital. When thinking about "too much" Digital we may divide it in four big areas: Digital Obesity/Overweight, Digital Sickness, Digital Addiction/Overdose and Digital Accident/Death. It is important to understand the impact of Digital in order to use it to make our $\mathrm{HI}$ as close to $100 \%$ as possible. There is evidence for the existence of these problems and that they are deserving increasing interest by researchers. We believe, however, that there is a lot more work to do in what concerns other impacts of overuse of Digital that may result on more evidence supporting any of this areas, but also evidence that require the creation of a new area. It is important that, sooner than later, we start to look to Digital Illness as a threat to our HI. This understanding of Digital will allow us to transform this threat in a way to potentiate our health to its maximum.

\section{ACKNOWLEDGEMENT}

The authors report no acknowledgment.

\section{REFERENCES}

Atchley, P. \& Strayer, D. L. 2017. Small Screen Use and Driving Safety. Pediatrics, 140, S107-s111.

Byyny, R. L. 2016. Information and cognitive overload: How much is too much? Pharos Alpha Omega Alpha Honor Med Soc, 79, 2-7.

Eichenberg, C., Schott, M., Decker, O. \& Sindelar, B. 2017. Attachment Style and Internet Addiction: An Online Survey. J Med Internet Res, 19, e170.

Kircaburun, K. \& Griffiths, M. D. 2018. Instagram addiction and the Big Five of personality: The mediating role of self-liking. J Behav Addict, 7, 158-170.

Klerings, I., Weinhandl, A. S. \& Thaler, K. J. 2015. Information overload in healthcare: too much of a good thing? Z Evid Fortbild Qual Gesundhwes, 109, 285-90.

Kuss, D. J. \& Griffiths, M. D. 2017. Social Networking Sites and Addiction: Ten Lessons Learned. Int J Environ Res Public Health, 14.

Lee, K., Roehrer, E. \& Cummings, E. 2017. Information overload in consumers of health-related information: a scoping review protocol. JBI Database System Rev Implement Rep, 15, 2457-2463.

Mihajlov, M. \& Vejmelka, L. 2017. Internet Addiction: A Review of the First Twenty Years. Psychiatr Danub, 29, 260-272.

Milne, J. 2019. Tackling the information overload in healthcare. Br J Nurs, 28, S3.

Ortiz, C., Ortiz-Peregrina, S., Castro, J. J., Casares-López, M. \& Salas, C. 2018. Driver distraction by smartphone use (WhatsApp) in different age groups. Accid Anal Prev, 117, 239-249.

Rathore, F. A. \& Farooq, F. 2020. Information Overload and Infodemic in the COVID-19 Pandemic. J Pak Med Assoc, 70(Suppl 3), S162-s165.

Reid Chassiakos, Y. L., Radesky, J., Christakis, D., Moreno, M. A. \& Cross, C. 2016. Children and Adolescents and Digital Media. Pediatrics, 138.

Sacks, D., Baxter, B., Campbell, B. C. V., Carpenter, J. S., Cognard, C., Dippel, D., Eesa, M., Fischer, U., Hausegger, K., Hirsch, J. A., Shazam Hussain, M., Jansen, O., Jayaraman, M. V., Khalessi, A. A., Kluck, B. W., Lavine, S., Meyers, P. M., Ramee, S., Rüfenacht, D. A., Schirmer, C. M. \& Vorwerk, D. 2018. Multisociety Consensus Quality Improvement Revised Consensus Statement for Endovascular Therapy of Acute Ischemic Stroke. Int J Stroke, 13, 612-632.

Steele, R. G., Hall, J. A. \& Christofferson, J. L. 2020. Conceptualizing Digital Stress in Adolescents and Young Adults: Toward the Development of an Empirically Based Model. Clin Child Fam Psychol Rev, 23, 15-26. 